\title{
Explorative in vitro evaluation of the inhibitory effect of Vitellaria paradoxa seed oil extract on Staphylococcal conjunctivitis
}

Chigozie John Ekenze 1, Samuel Monday Utin 1, Timothy Olugbenga Ogundeko 2, *, Oyinyechi Lilian Umunnakwe ${ }^{3}$, Lilian Chioma Owunna ${ }^{4}$, Nkiruka Philomena Okoye ${ }^{2}$ and Mamzhi Seljul Crown Ramyil 5

${ }^{1}$ Department of Optometry, Imo State University, Owerri Nigeria.

2 Department of Pharmacology and Therapeutics, College of Medicine and Health Sciences, Bingham University, Jos Campus, Nigeria.

${ }^{3}$ Department of Optometry, Federal University of Technology, Owerri Nigeria.

${ }^{4}$ Department of Optometry, Bingham University Teaching Hospital, Jos Nigeria.

${ }_{5}^{5}$ Department of Microbiology and Parasitology, College of Medicine and Health Sciences, Bingham University, Jos Campus, Nigeria.

Magna Scientia Advanced Biology and Pharmacy, 2022, 05(01), 001-007

Publication history: Received on 15 November 2021; revised on 23 December 2021; accepted on 25 December 2021

Article DOI: https://doi.org/10.30574/msabp.2022.5.1.0052

\begin{abstract}
More exploration on medicinal plants and other natural products in the present era of increase in poverty level and multi-drug resistance has become crucial. The aim of this study is to explore the inhibitory activities of Vitellaria paradoxa seed oil extract on isolated staphylococcal conjunctivitis. Cultured sample of Staphylococcus aureus isolated from a patient's eye discharge in the Teaching Hospital Laboratory of the Imo State University, Nigeria having been diagnosed with bacterial conjunctivitis at the eye Clinic. After the incubation period, the diameter of zones of inhibition both horizontal and vertical were measured. Concentrations $(100,50$ and $25 \mathrm{mg} / \mathrm{ml}$ ) of the ethanolic seed oil extract of $V$. paradoxa were assayed for the antibacterial activity - Minimum Inhibitory Concentration (MIC) using the agar well diffusion method. Ethanolic seed oil extract of $V$. paradoxa at concentration of $100 \mathrm{mg} / \mathrm{ml}$ exhibited the highest zone of inhibition at $37.4 \mathrm{~mm}$ for $24 \mathrm{hrs}$ followed by $50 \mathrm{mg} / \mathrm{ml}$ and lowest using $25 \mathrm{mg} / \mathrm{ml}(5.0 \mathrm{~mm})$ indicating a concentrationdependent inhibitory effect on Staphylococcal conjunctivitis. S. aureus isolated from conjunctivitis swab was susceptible to ethanolic seed oil extract of $V$. paradoxa at $100 \mathrm{mg} / \mathrm{ml}, 50 \mathrm{mg} / \mathrm{ml}$ and $25 \mathrm{mg} / \mathrm{ml}$ concentrations, suggesting ethanolic extract of V. paradoxa oil as possessing antimicrobial property. Further exploration for its use as an ocular anti-bacterial agent is recommended.
\end{abstract}

Keywords: Inhibitory activity; Shea butter; Dose dependent; Inhibition zone; Oil separation

\section{Introduction}

Traditional medicine/complementary alternative medicine may suggest new ideas to modern medicine in order to face new challenges however these concepts should be acknowledged based on experimental studies [1]. Herbal plants have played an important role traditional medicine therapy of multiple human illnesses since the existence of man in many parts of the globe. The most common eye diseases include conjunctivitis, cataract, glaucoma, eye allergies, eye inflammation. The problem of adverse drug effects of modern drugs, has led to the increased use nowadays of herbal remedies in the treatment of eye diseases [2]. About two centuries ago in,'Makhzan-O-L Advieh,'a famous Iranian traditional pharmacopoeia, written by Mohammad Hossein Aghili Khorasani Shirazi (d. 1772 AD), one of the most significant Persian physicians, onion was prescribed for the prevention and treatment of a number of eye diseases,

\footnotetext{
${ }^{*}$ Corresponding author: Timothy Olugbenga Ogundeko

Department of Pharmacology and Therapeutics, College of Medicine and Health Sciences, Bingham University, Jos Campus, Nigeria. Copyright $(2022$ Author(s) retain the copyright of this article. This article is published under the terms of the Creative Commons Attribution Liscense 4.0.
} 
including; cataract, epiphora and blepharitis [3]. Plant materials are still being prescribed by traditional healers and herbalists for the treatment of these infections [4].

Available studies on use of Traditional Eye Medicine (TEM) in normal subjects are either hospital-based or have mostly been done in the African countries [5]. Interestingly, the reported prevalence of use of Traditional eye medicine in a hospital-based studies in Nigeria was 13.2\%. [6]. Use of traditional eye medicine is prevalent in this population. The rampant use of steroid eye drops without prescription along with use of expired or unlabeled eye drops warrants greater emphasis on safe eye care practices in this population. Public awareness and regulatory legislations must be implemented to decrease harmful effects arising due to such practices [7]. Shea butter is a vegetable fat extracted from the kernel of the fruit of the shea tree (Vitellaria paradoxa), a tree belonging to the family of sapotaceae. The tree is the main indigenous oil producing wild plant spontaneously growing in Africa [8]. The shea tree (Vitellaria paradoxa) grows naturally or as a cultivated tree corp in the dry Savannah belt of West Africa.

The West Africa subspecies is V. paradoxa var. nilotica and occurs in 19 countries across the African continent, with Benin, Ghana, Burkina Faso and Cote D'Ivoire, as the major producers [9]. It is a perennial tropical tree that grows to the height range of $15-20 \mathrm{~m}$, the fruits fall when fully ripened. The Shea nut butter obtained from the fruits of shell tree is also known as Chamen, Kandayi/Mankade, Osisi/Okwuma and Emi/Orioyo among the Tiv, Hausa, Igbo and Yoruba people of Nigeria, respectively [10] (Julius et al., 2013). [11] Hee, (2011) reported that shea tree begins to bear fruit of commercial quantities after approximately 20 to 50 years. Vitellaria paradoxa (Gaertn C. F.), or shea tree, remains one of the most valuable trees for farmers in the Atacora district of northern Benin, where rural communities depend on shea products for both food and income [12]. The shea tree grows extensively in the northern part of Ghana, which is known to be one of the poorest areas in the country [13]. Shea butter is a high-value shea nut fat used as an edible oil, antimicrobial and moisturiser in the food, pharmaceutical and cosmetic industries, respectively. The annual worldwide export of shea nut from Africa is $350,000 \mathrm{MT}$ of kernels with a market value of approximately $\$ 120$ million to producing countries [14].

The Nigerian agricultural industries have the potentials to contribute significantly to the economic and industrial development of the nation, especially with the wide range of the nation's agro-produce like Shea trees [15]. Chen et al., (2019) suggested that SheaFlex75 may be an effective management strategy for symptom relief and cartilage protection in patients with both acute and chronic OA [16]. Olasunkanmi et al., (2017) and Kalgo et al., (2019) also reported that shea butter has antioxidant constituents with antibacterial and antifungal activities as well as immunomodulatory properties $[17,18]$.

The vascularized nature of the conjunctiva coupled with its exposure to dust, wind, heat and radiation makes it to easily get infected [19]. Ocular tissues are vulnerable to Staphylococcus aureus infection due to the exposed nature of the eyes. Among the pathogenic bacteria, Staphylococcus aureus is the most common cause of ocular infection by Gram-positive bacteria second only to Pseudomonas aeruginosa, causing ocular diseases such as conjunctivitis, blepharitis, blepharoconjunctivitis, corneal ulcer, dacryocystitis, orbital cellulitis and dacryoadenitis [20]. Staphylococcus aureus is the most common cause of bacterial conjunctivitis, blepharoconjunctivitis and keratoconjunctivitis [21]. Medical practitioners consider drug resistant micro-organisms a major problem in the treatment of sick individuals (Lepape et al., 2019) [22].

The aim of this study is to explore the inhibitory activities of Vitellaria paradoxa seed oil extract on isolated staphylococcal conjunctivitis.

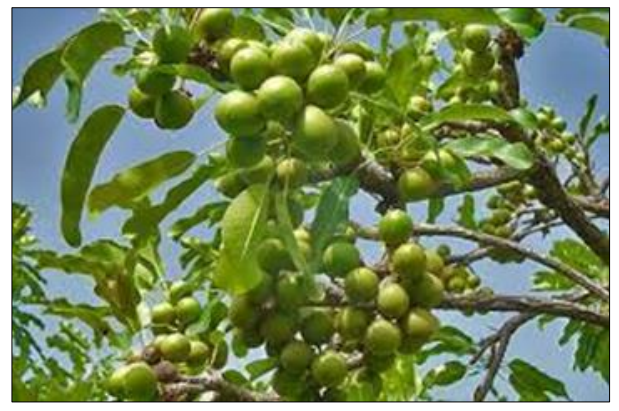

Figure 1 Shea butter tree [23]

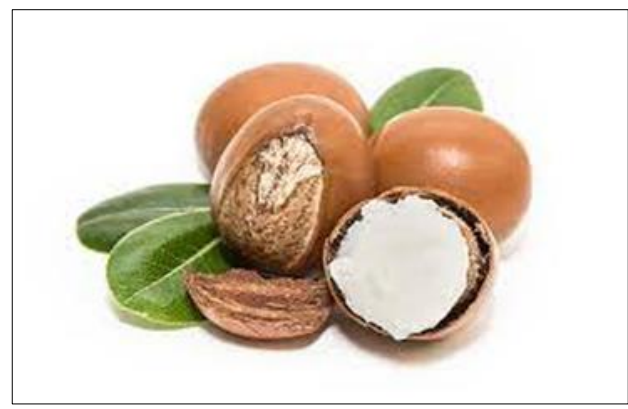

Figure 2 Shea butter seed [24] 


\section{Material and methods}

\subsection{Study site}

The research was carried out KENTEC Medical Laboratory, Owerri, Imo State Nigeria.

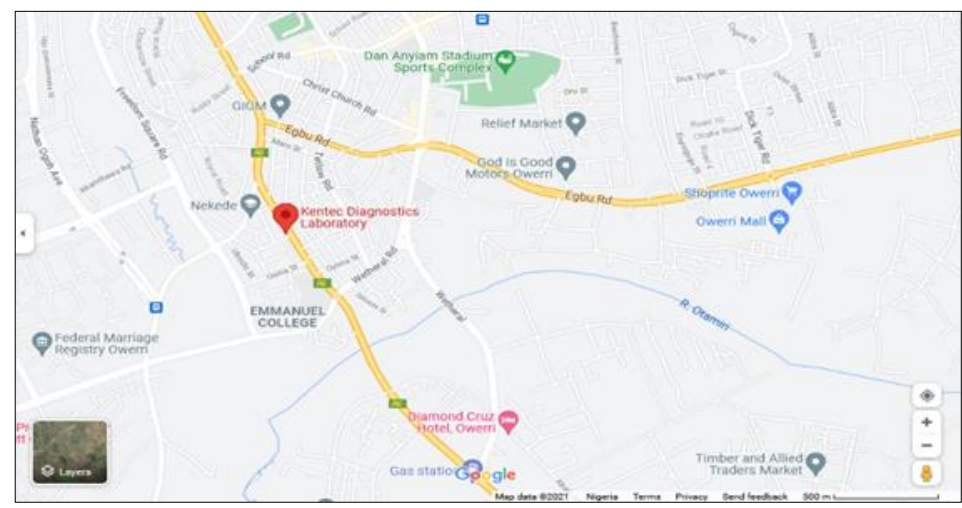

Figure 3 Google map showing KENTEC Medical Laboratory [25]

\subsection{Plant material procurement, preparation and extraction}

Fully matured fruits (nuts) of shea butter (Vitellaria paradoxa) were purchased from Douglas market in Owerri LGA of Imo state, Nigeria in mid-July, 2019. The plant material was identified and authenticated at the Department of plant science and Biotechnology, Imo State University, Owerri, Nigeria.

The seeds were cracked in order to remove the kernels after which $400 \mathrm{~g}$ was weighed, oven-dried, crushed, ground and kneaded to obtain a paste. Subsequently, $250 \mathrm{~g}$ of the paste was weighed into a $500 \mathrm{ml}$ beaker with the addition of $120 \mathrm{ml}$ $\mathrm{H}_{2} \mathrm{O} 85^{\circ} \mathrm{C}$ and $230 \mathrm{ml}$ of ethanol and allowed to stand for 24 hours in order to allow for oil separation followed by decantation (Julius et al., 2013) [26]. This was stored in an airtight glass container.

\subsection{Extract concentration preparation}

Three different concentrations $(100,50$ and $25 \mathrm{mg} / \mathrm{ml})$ of the ethanolic seed oil extract of $V$. paradoxa were prepared using 10\% Dimethyl Sulphur Oxide (DMSO) as a diluent according to the method of Julius et al., 2013[26]. The plant extracts assayed for the antibacterial activity, Minimum Inhibitory Concentration (MIC) using the agar well diffusion method were also employed.

\subsubsection{Antibacterial assay}

Cultured sample Staphylococcus aureus isolated from a patient's eye discharge in the Teaching Hospital Laboratory of the Imo State University, Nigeria having been diagnosed with bacterial conjunctivitis at the eye Clinic. This was transported to KENTEC Medical Laboratory, Owerri, Imo State Nigeria for analysis.

Wells were made using a sterile cock borer $(6 \mathrm{~mm})$, filled with $50 \mu \mathrm{L}$ of each concentration $(100,50 \mathrm{and} 25 \mathrm{mg} / \mathrm{ml})$ of the ethanolic seed oil extract of $V$. paradoxa. Bacterial suspension was added into each of the wells containing the crude extract. The inoculated plates were then left at room temperature for $30 \mathrm{~min}$ for the extract to evenly diffuse and later incubated at $37^{\circ} \mathrm{C}$ for 24 hours. Thereafter, the diameter of zones of inhibition both in horizontal and vertical meridians were measured in millimeters ( $\mathrm{mm}$ ) using a calibrated ruler, while results were interpreted according to N. Gurnani et al., 2016 guidelines [27].

The diluted standardized bacterial suspension was added into each of the wells containing the serially diluted crude extract. This was mixed to homogeneity to give a final inoculum of $5 \times 10^{5} \mathrm{CFU} / \mathrm{ml} \mathrm{S.} \mathrm{Vijayarathna} \mathrm{et} \mathrm{al.,} 2012$ [28].

\subsection{Statistical analysis}

The data were presented in bar charts and subjected to one-way analysis of variance using SPSS version 20.0 (Statistical Package for the Social Sciences, Inc., Chicago, IL, United States). Differences between means were considered significant at $p$-value $<0.05$. 


\section{Results and discussion}

Our study results revealed that the zone of inhibition on Staphylococcus aureus with $100 \mathrm{mg} / \mathrm{ml}$ concentration of ethanolic seed oil extract of Vitellaria paradoxa increased with increase in time - Figure 4.

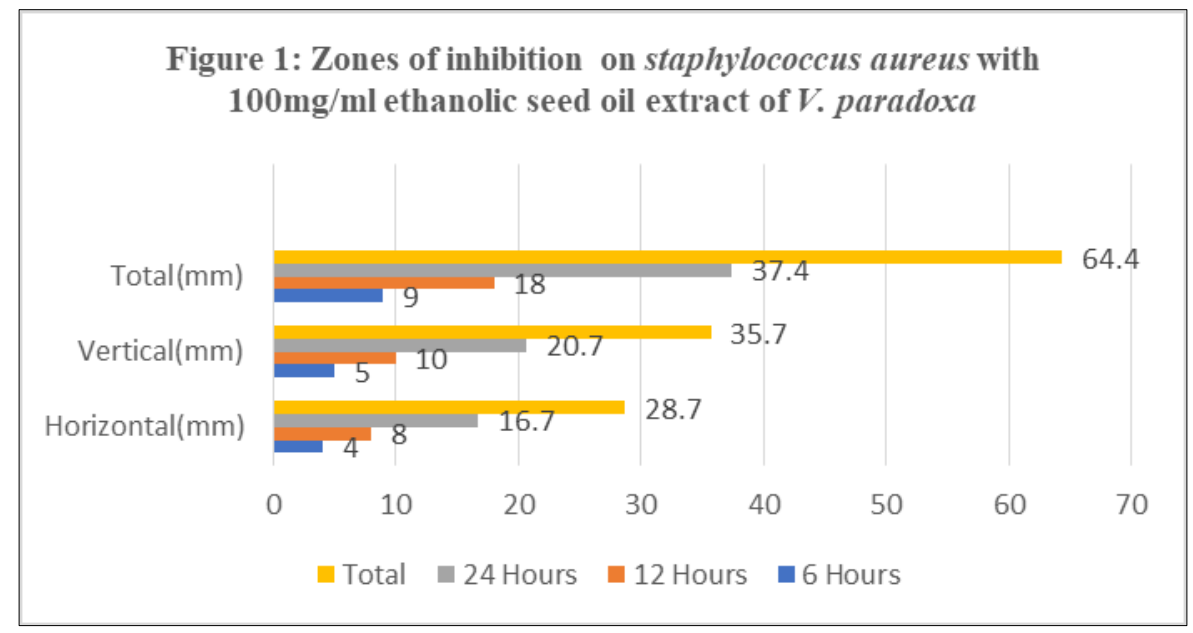

Figure 4 Zones of inhibition on S. aureus with $100 \mathrm{mg} / \mathrm{ml}$ ethanolic seed oil extract of $V$. paradoxa

At 6hours, the zone of inhibition increased to $9.0 \mathrm{~mm}$, at 12 hours, the zone of inhibition increased further to $18.0 \mathrm{~mm}$ and at 24 hours, the zone of inhibition got to $37.4 \mathrm{~mm}$ - Figure 4.

Same trend of increase in zones of inhibition with time was also observed in staphylococcus aureus with $50 \mathrm{mg} / \mathrm{ml}$ shea butter concentration having $7.0 \mathrm{~mm}, 14.8 \mathrm{~mm}$ and $30.6 \mathrm{~mm}$ at 6,12 and 24 hours respectively - Figure 5 .

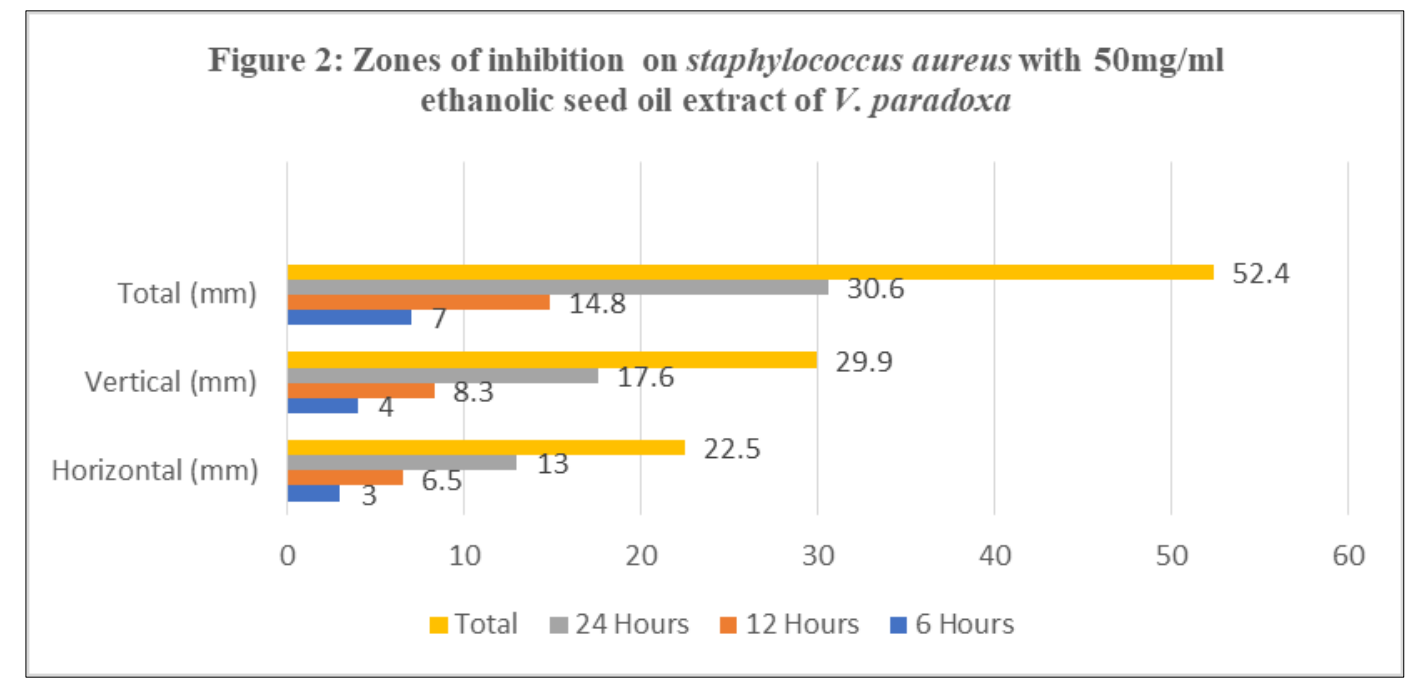

Figure 5 Zones of inhibition on S. aureus with $50 \mathrm{mg} / \mathrm{ml}$ ethanolic seed oil extract of $V$. paradoxa

Figure 6 showed zones of inhibition on staphylococcus aureus with $25 \mathrm{mg} / \mathrm{ml}$ shea butter concentration. At 6 hours, the zone of inhibition increased to $5.0 \mathrm{~mm}$ while at 12 and 24 hours, it was further increased to $11.0 \mathrm{~mm}$ and $23.9 \mathrm{~mm}$ respectively. This also depicts increase in zone of inhibition as time increase. 


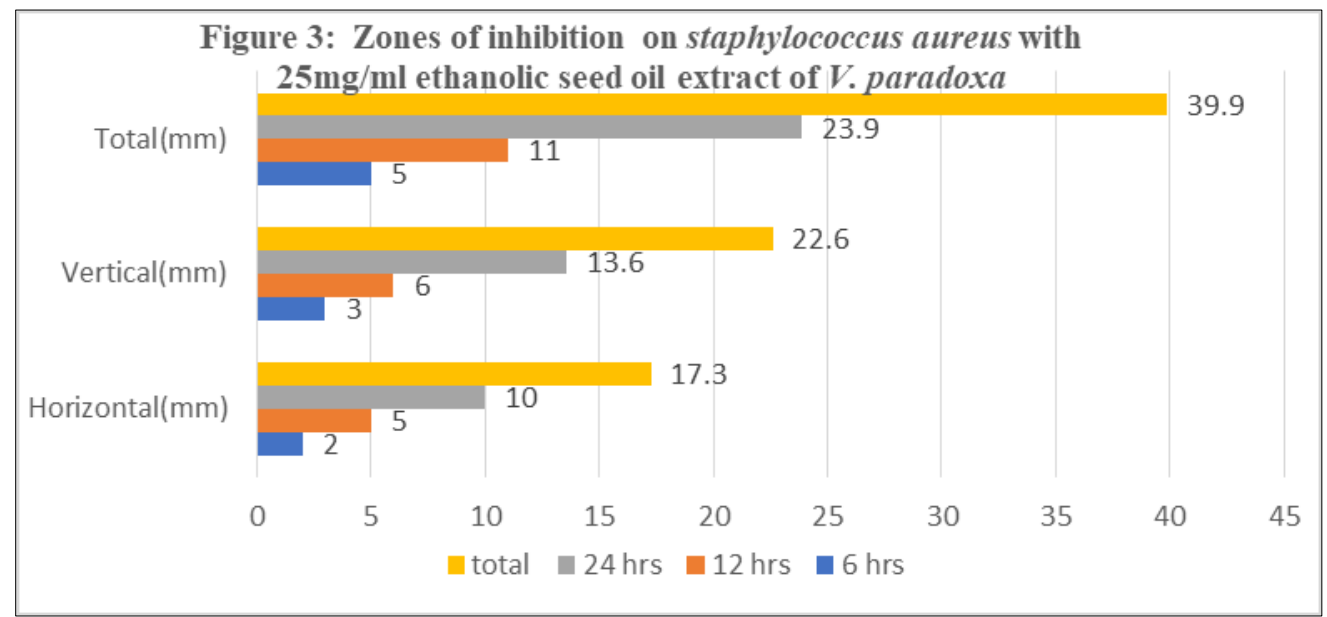

Figure 6 Zones of inhibition on $S$. aureus with $25 \mathrm{mg} / \mathrm{ml}$ ethanolic seed oil extract of V. paradoxa

The zone of inhibition by the ethanolic seed oil extract of $V$. paradoxa with highest diameter of $100 \mathrm{mg} / \mathrm{ml}(37.4 \mathrm{~mm})$ at $24 \mathrm{hrs}$ time interval for both horizontal and vertical diameters (Figure 4) and lowest as shown using $25 \mathrm{mg} / \mathrm{ml}$ (5.0mm) also for both horizontal and vertical at 6hrs time interval (Figure 6) indicated that the higher the concentration of $V$. paradoxa, the greater its inhibitory effect on Staphylococcal conjunctivitis, thus, its inhibitory effect was concentration dependent. In other words, decrease in different shea butter concentration led to a direct reduction of the zone of inhibition around the staphylococcus aureus. Similar observation by Adamu et al., (2013) [29] and Arekemase, et al., (2013) [30] had suggested that higher concentration of antimicrobial compounds gave appreciable antimicrobial efficacy.

The pattern of antimicrobial activities of the plant extracts and the zone of inhibition of the bacteria are in consonance with Ekhuemelo et al., 2021 [31], that asserted that the zones of inhibition of $V$. paradoxa fractions (18 - $24 \mathrm{~mm})$ were at the same range of $25 \mathrm{~mm}-31 \mathrm{~mm}$ recorded for three control antibiotics. The plant extract of V. paradoxa seed oil had profound activities against staphylococcus with higher concentration as varying degrees of inhibition against gram positive bacteria was observed. The marked difference in the effect of the extracts on the organism therefore is suggestive of the activity against cell wall components of the organism. The antimicrobial substance appears to exert antimicrobial activity by increasingly inhibiting the growth of ethanolic seed oil extract of $V$. paradoxa at $100 \mathrm{mg} / \mathrm{ml}$, $50 \mathrm{mg} / \mathrm{ml}$ and $25 \mathrm{mg} / \mathrm{ml}$ respectively.

\section{Conclusion}

Staphylococcus aureus isolated from conjunctivitis swab was susceptible to ethanolic seed oil extract of $V$. paradoxa at $100 \mathrm{mg} / \mathrm{ml}, 50 \mathrm{mg} / \mathrm{ml}$ and $25 \mathrm{mg} / \mathrm{ml}$ concentrations as it inhibited the growth of Staphylococcal conjunctivitis, thus, ethanolic extract of $V$. paradoxa oil possess antimicrobial property. Further exploration for its use as an ocular antibacterial agent is recommended.

\section{Compliance with ethical standards}

\section{Acknowledgments}

Authors wish to thank Dr AU Akujobi and Dr JE Obioma-Elemba for their supervisory and mentoring roles. A special thanks for the management of KENTEC Medical Laboratories, Owerri, Nigeria.

\section{Disclosure of conflict of interest}

All authors hereby declare no conflicting interest.

\section{Statement of ethical approval}

This was obtained from the Department of optometry, Imo State University, Owerri, Nigeria. 


\section{Statement of informed consent}

Study does not require consent; hence not applicable.

\section{References}

[1] Nejabat M, Salehi A, Azad PN, Ashraf MJ. Effects of onion juice on the normal flora of eyelids and conjunctiva in an animal model. Jundishapur J Microbiol. 2014 May; 7(5): e9678.

[2] Dorcas W, Emilliene E, Estella T, Joseph E. A, Kovin N, Jaggernath J, Timothy W, Ngo N, Therese AO, Ntungwen F. An Overview of Herbal Traditional Eye Care Practices and the Development of Eye Health Promotion Strategies in Cameroon. Journal of Advances in Medical and Pharmaceutical Sciences. 2019; 20(4): 1-16.

[3] Aghili Khorasani Shirazi MH. Makhzan al-Advieh. Tehran: Iran University of Medical Sciences. 2010.

[4] Mitchell H, Friedlaender MD. Clinical Therapeutics. 1995; 17: 800-810.

[5] Jaya Y, Masanganise R. The prevalence, types and effects of traditional eye medicine use among newly presenting patients at Sekuru Kaguvi Hospital Eye Unit in Harare, Zimbabwe. Cent Afr J Med. 2014; 60: 36-44.

[6] Nwosu SN, Obidiozor JU. Incidence and risk factors for traditional eye medicine use among patients at a tertiary eye hospital in Nigeria. Niger J Clin Pract. 2011; 14: 405-407.

[7] Gupta N, Vashist P, Tandon R, Gupta SK, Kalaivani M, Dwivedi SN. Use of traditional eye medicine and selfmedication in rural India: A population-based study. PLoS ONE. 2017; 12(8): e0183461.

[8] Honfo FG, Hell K, Akissoe N, Hinnemann A, Coulibaly O. Microbiological and physicochemical characterization of shea butter sold in Benin market. J Stored Prod and Postharv Res. 2012; 3(3): 24-29.

[9] FAO. Appendix 5, Forest genetic resource priorities. Africa. Report of Sixth Session of the FAO Panel of Experts on Forest Gene Resources, held in Rome, Italy, Dec. 8-11, 1985, FAO, Rome. 1988; 86-89.

[10] Ikya JK, Umenger LN, Iorbee A, 2013. Effects of Extraction Methods on the Yield and Quality Characteristics of Oils from Shea Nut. Journal of Food Resource Science. 2013; 2: 1-12.

[11] Hee SN. Quality characteristics of west african shea butter (vitellaria paradoxa) and approaches to extend shelflife. [M.Sc Thesis] Graduate School-New Brunswick Rutgers, The State University of New Jersey. 2011.

[12] Aleza K, Villamor GB, Nyarko BK, Wala K, Akpagana K. Shea (Vitellaria paradoxa Gaertn C. F.) fruit yield assessment and management by farm households in the Atacora district of Benin. PLoS ONE. 2018; 13(1): e0190234.

[13] Gyedu-Akoto E, Amon-Armah F, Yabani D. Utilization of shea fruit to enhance food security and reduce poverty in Ghana. Afri J Sci, Tech, Innov and Dev. 2017; 9(6): 697-705.

[14] Iddrisu AB, Didia B, Adam A. African Journal of Biochemistry Research Shea butter extraction technologies: Current status and future perspective. Afri J Bioch Res. 2019; 13(2): 9-22.

[15] Garba ID, Nwaw C N, Osiakede I L. The potential of shea nut tree to the Nigerian economy. Int J Agric Econ \& Rural Dev. 2011; 62-72.

[16] Chen IJ, Lin SH, Wong CS. Oral shea nut oil triterpene concentrate supplement ameliorates pain and histological assessment of articular cartilage deterioration in an ACLT injured rat knee osteoarthritis model. PLoS One. 2019; 14(4): e0215812.

[17] Olasunkanmi O0, Akinpelu DA, Adeniyi PO, Ajayi OF, Omololu-Aso J, Olorunmola FO. Investigation into Antibacterial, Phytochemical and Antioxidant Properties of Vitellaria paradoxa (Gaertn.) Stem Bark Extracts. J. Pharma. Res. Intern. 2017; 20(5): 1-17.

[18] Kalgo MU, Hamid KM, Muhammad UA, Balarabe A, Yeldu MH, Yahaya IS, Kalgo ZM, Aliyu B, YG. Bala Effects of aqueous stem bark extract of Vitellaria paradoxa on human neutrophil function and viability. Intern. J. Biolog. \& Med. Res. 2019; 10(3): 6782-6787.

[19] Ekenze CJ, Umunnakwe OL, Ogundeko TO, Owunna CL, Mbatuegwu FA, Ramyil MSC. Antimicrobial activity of selected aminoglycoside and fluoroquinolone eye drops against Staphylococcus aureus isolated from the conjunctiva of a bacterial conjunctivitis patient. IJSRA. 2021; 02(02): 151-157.

[20] Khurana AK, Khurana B. Comprehensive ophthalmology. 5th ed. New Dehli: New Age Publishers, India. 2012. 
[21] Nema HV, Ntin N. Textbook of ophthalmology. 5th ed. New Dehli: Jaypee brothers' publishers Ltd. India. 2008.

[22] Lepape A, Jean A, De Waele J, et al. European intensive care physicians' experience of infections due to antibioticresistant bacteria. Antimicrob Resist Infect Control. 2020; 9: 1.

[23] Shea Butter Tree. Shea butter tree of life, Puru, 100 naturals, vegan. Available through: https://puru.ch/wpcontent/uploads/2019/05/SHEA-BUTTER-TREE-OF-LIFE-PURU-100-natural-vegan. [Accessed22 September 2021].

[24] Shea butter seed. Buy shea butter for export on cokodeal. Available through: https://www.cokodeal.com [Accessed 22 September 2021]

[25] Google Maps, 2021. KDL: Kentec Diagnostics Laboratory, Owerri, Imo State, Nigeria. Google Maps [online] Available through: https://vymaps.com/NG/ - feature- 285596 [Accessed16 October, 2021].

[26] Julius K Ikya, Lilly N Umenger, Ayangealumun Iorbee. Effects of Extraction Methods on the Yield and Quality Characteristics of Oils from Shea Nut. Journal of Food Resource Science. 2013; 2: 1-12.

[27] Gurnani N, Gupta M, Shrivastava R, Mehta D, Mehta BK, Effect of extraction methods on yield, phytochemical constituents, antibacterial and antifungal activity of Capsicum frutescens L, Indian J Nat Prod \& Resourc. 2016; (7): 32-39.

[28] Vijayarathna S, Zakaria Z, Chen Y, Latha LY, Kanwar JR, Sasidharan S. The antimicrobial efficacy of Elaeis guineensis: characterization, in vitro and in vivo studies. Molecules. 2012; 17(5): 4860-4877.

[29] Adamu HM, Ushie OA, Nansel E. Antimicrobial activity of oil from shea butter. Intern J Mod Biol \& Med. 2013; 3(2): 50-59.

[30] Arekemase MO, Oyeyiola GP, Balogun KI. Assessment of bitter leaf on some selected Pathogenic organisms. J Microbiol, Biotech \& Food Serv. 2013; 2(5): 2360-2365.

[31] Ekhuemelo DO, Anyam JV, Ekhuemelo C. Antimicrobial Efficacy of Vitellaria paradoxa fractions and compounds on some wood Fungi and Bacteria. Nig. J. Biotech. June 2021; 38(1): 1-13. 